\title{
Airborne formaldehyde measurements using PTR-MS: calibration, humidity dependence, inter-comparison and initial results
}

\author{
C. Warneke ${ }^{1,2}$, P. Veres ${ }^{1,2, *}$, J. S. Holloway ${ }^{1,2}$, J. Stutz ${ }^{3}$, C. Tsai ${ }^{3}$, S. Alvarez ${ }^{4}$, B. Rappenglueck ${ }^{4}$, F. C. Fehsenfeld ${ }^{1,2}$, \\ M. Graus ${ }^{1,2}$, J. B. Gilman ${ }^{1,2}$, and J. A. de Gouw ${ }^{1,2}$ \\ ${ }^{1}$ NOAA Earth Systems Research Laboratory, Chemical Sciences Division, Boulder, CO, USA \\ ${ }^{2}$ CIRES, University of Colorado, Boulder, CO, USA \\ ${ }^{3}$ University of California, Los Angeles, USA \\ ${ }^{4}$ University of Houston, Houston, Texas, USA \\ *now at: Max Planck Institute, Mainz, Germany
}

Received: 9 June 2011 - Published in Atmos. Meas. Tech. Discuss.: 21 July 2011

Revised: 17 October 2011 - Accepted: 19 October 2011 - Published: 31 October 2011

\begin{abstract}
We present quantitative, fast time response measurements of formaldehyde (HCHO) onboard an aircraft using a Proton-Transfer-Reaction Mass-Spectrometry (PTRMS) instrument. The HCHO measurement by PTR-MS is strongly humidity dependent and therefore airborne measurements are difficult and have not been reported. The PTR-MS instrument was run in the standard PTR-MS operating mode (de Gouw and Warneke, 2007), where about 15 volatile organic compounds (VOCs) are measured together with HCHO onboard the NOAA WP-3 aircraft during the CalNex 2010 campaign in California. We compare the humidity dependence determined in the laboratory with in-flight calibrations of $\mathrm{HCHO}$ and calculate the HCHO mixing ratio during all flights using the results from both. The detection limit $(S / N=1)$ for HCHO was between $100 \mathrm{pptv}$ in the dry free troposphere and $300 \mathrm{pptv}$ in the humid marine boundary layer for a one second acquisition time every $17 \mathrm{~s}$. The PTR-MS measurements are compared with HCHO measurements using a DOAS instrument and a Hantzsch monitor at a ground site in Pasadena. The PTR-MS agreed with the DOAS within the stated uncertainties and was just outside the uncertainties with the Hantzsch. We also compare HCHO enhancement ratios in the Los Angeles basin and in the free troposphere with literature values and find good agreement. The usefulness of the PTR-MS HCHO measurements in atmospheric observations is demonstrated by following an isolated anthropogenic plume. The photochemical production
\end{abstract}

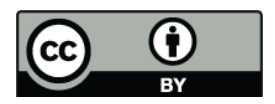

Correspondence to: $\mathrm{C}$. Warneke (carsten.warneke@noaa.gov) of $\mathrm{HCHO}$ can be observed simultaneously with production of acetaldehyde and the photochemical degradation of aromatic compounds using the PTR-MS. The results show that PTR-MS seems a useful instrument to measure $\mathrm{HCHO}$, but more inter-comparisons are needed.

\section{Introduction}

Formaldehyde (HCHO) is one of the most abundant volatile organic compounds (VOCs) in the atmosphere. The mixing ratios range from about $100 \mathrm{pptv}$ in remote areas (Sumner et al., 2002; Fried et al., 2008) to several tens of ppbv in polluted areas (Dasgupta et al., 2005; Kormann et al., 2003). The primary emission sources of $\mathrm{HCHO}$ include biomass burning (Yokelson et al., 1996; Holzinger et al., 1999) and anthropogenic sources such as vehicle exhaust (Dasgupta et al., 2005; Zavala et al., 2009; Garcia et al., 2006; Ban-Weiss et al., 2008), but overall the primary emissions are small compared to the secondary production (Garcia et al., 2006; $\mathrm{Li}$ et al., 1994). HCHO is produced in the atmosphere from many different compounds (Lee et al., 1998), where important precursors are alkenes such as ethylene (Washenfelder et al., 2010; Gilman et al., 2009) and isoprene, and alkanes such as methane (Finlayson-Pitts and Pitts, 1986). Isoprene, which has the largest global emissions of all VOCs (Guenther et al., 2000), produces $\mathrm{HCHO}$ as a first-generation product in the presence of NOx and satellite measurements of $\mathrm{HCHO}$ can be used to estimate the isoprene emissions on large spatial scales (Millet et al., 2008; Palmer et al., 2006). 
$\mathrm{HCHO}$ has a short lifetime of only a few hours during the day due to reactions with $\mathrm{OH}$ and photolysis, which makes it an important compound in the formation of ozone and the cycling of $\mathrm{HO}_{\mathrm{x}}$ radicals (Lowe and Schmidt, 1983). In an urban area the photolysis of HCHO is one of the most important radical sources sustaining photochemical ozone formation (Volkamer et al., 2010), which also makes HCHO one of the key indicators of atmospheric photochemical activity.

Various analytical techniques are available for ambient HCHO measurements. Commonly used instruments are tunable diode laser absorption spectrometer (TDLAS) (Wert et al., 2003; Fried et al., 2002), difference frequency generation absorption spectrometer (DFGAS) (Weibring et al., 2007), laser induced fluorescence (LIF) (Hottle et al., 2009), commercially available wet chemical sensors based on Hantzsch fluorometry (Junkermann and Burger, 2006; Kelly and Fortune, 1994), Fourier transform infrared spectroscopy (FTIR) (Yokelson et al., 1996), cartridges for 2,4dinitrophenylhydrazine (DNPH) derivatization followed by off-line high pressure liquid chromatography (HPLC) analysis (Grosjean and Fung, 1982), and pulsed quantum cascade laser spectrometer (QCL) (Herndon et al., 2007). Other instruments that are commonly used are based on long-path techniques such as the differential optical absorption spectrometer (DOAS) (Lawson et al., 1990) and the multi-axes differential optical absorption spectroscopy (MAX-DOAS) (Heckel et al., 2005). A table with instrumental details on most of the techniques listed above can be found in Wisthaler et al. (2008).

In a recent formal inter-comparison exercise at the SAPHIR chamber between five different $\mathrm{HCHO}$ analyzers using four different techniques it was found that significant analytical problems exist for most of the techniques (Wisthaler et al., 2008). Even though this inter-comparison varied humidity and ozone levels, it was nonetheless a laboratory simulation, which is one of the least challenging environments for the analyzers. Field measurements, especially aircraft measurements, present a much more challenging environment, complicating the $\mathrm{HCHO}$ measurements (Wert et al., 2003; Herndon et al., 2007).

Recently Proton-Transfer-Reaction Mass-Spectrometry (PTR-MS) has been used to measure $\mathrm{HCHO}$ in the atmosphere and laboratory settings despite various analytical challenges (Vlasenko et al., 2010; Karl et al., 2003; Steinbacher et al., 2004; Inomata et al., 2008; Wisthaler et al., 2008; Holzinger et al., 1999). Because the reaction of $\mathrm{H}_{3} \mathrm{O}^{+}$ with $\mathrm{HCHO}$ is only slightly exothermic and the back reaction becomes important at typical PTR-MS instrument settings, the HCHO detection by PTR-MS is strongly humidity dependent and overall less sensitive than for other compounds (Hansel et al., 1997). To improve on the humidity dependence and the lowered sensitivity, in some measurements instrument settings were changed (Wisthaler et al., 2008) or the sample stream was dried (Jobson and McCoskey, 2010), but might influence the ability of PTR-MS to measure multiple compounds important in atmospheric ambient measurements at the same time.

In this paper we further explore the capability of PTR-MS to reliably measuring $\mathrm{HCHO}$ on board an aircraft together with all other VOCs typically measured by PTR-MS. The measurements were done on board the NOAA WP-3 aircraft during the CalNex campaign in California 2010 (California at the Nexus of Air Quality and Climate). The PTR-MS was run at the standard instrument settings (de Gouw and Warneke, 2007) and simultaneous measurements were made of oxygenated VOCs such as methanol and acetone, biogenic compounds such as isoprene and monoterpenes and aromatics such as benzene and toluene. As a validation of the measurements we compare to $\mathrm{HCHO}$ measurements on a ground site in Pasadena during overflights. Furthermore, a plume study will be used to show the atmospheric $\mathrm{HCHO}$ production within the plume evolution.

\section{Experimental}

\subsection{PTR-MS instrument and HCHO detection}

The PTR-MS instrument used in this study was described in detail by de Gouw and Warneke (2007) and was used in similar configurations in multiple aircraft and ground based experiments. Briefly, $\mathrm{H}_{3} \mathrm{O}^{+}$is produced in a hollow cathode ion source and allowed to react with VOCs that have a higher proton affinity (PA) than $\mathrm{H}_{2} \mathrm{O}$ in a reaction chamber. The resulting $\mathrm{VOCH}^{+}$ions are detected together with the primary ions using a quadrupole mass spectrometer. The instrument was operated at a pressure of $2.4 \mathrm{mbar}$ and an electric field of $70 \mathrm{~V} \mathrm{~cm}^{-1}(E / N=130 \mathrm{Td})$ in the reaction chamber at a temperature of $45^{\circ} \mathrm{C}$. $\mathrm{O}_{2}^{+}$produced in the ion source and detected on mass 32 was always kept below $2 \%$. During the flights 14 masses corresponding to different VOCs, including mass 31 for $\mathrm{H} \cdot \mathrm{HCHO}^{+}$, were measured for one second each together with the primary ions resulting in a 16-s duty cycle. Instrument backgrounds were determined every $13 \mathrm{~min}$ for 1 min using a catalytic converter, which is described in more detail below.

HCHO has only a slightly higher PA than water $\left(165.2 \mathrm{kcal} \mathrm{mol}^{-1}\right.$ for $\mathrm{H}_{2} \mathrm{O}$ and $170.4 \mathrm{kcal} \mathrm{mol}^{-1}$ for $\mathrm{HCHO}$ ), which is so small that the back reaction becomes significant:

$$
\mathrm{H}_{3} \mathrm{O}^{+}+\mathrm{HCHO} \stackrel{k_{\mathrm{R} 1}}{\longrightarrow} \mathrm{H} \cdot \mathrm{HCHO}^{+}+\mathrm{H}_{2} \mathrm{O}
$$

$\mathrm{H} \cdot \mathrm{HCHO}^{+}+\mathrm{H}_{2} \mathrm{O} \stackrel{k_{\mathrm{Rla}}}{\longrightarrow} \mathrm{H}_{3} \mathrm{O}^{+}+\mathrm{HCHO}$.

The rate coefficients are $k_{\mathrm{R} 1}=1.4 \times 10^{-9} \mathrm{~cm}^{3} \mathrm{~s}^{-1}$ molecule ${ }^{-1}$ and $k_{\mathrm{R} 1 \mathrm{a}}=3-5 \times 10^{-11} \mathrm{~cm}^{3} \mathrm{~s}^{-1}$ molecule ${ }^{-1}$ (Vlasenko et al., 2010; Hansel et al., 1997) and [HCHO], $\left[\mathrm{H}_{3} \mathrm{O}^{+}\right]$and $\left[\mathrm{H}_{2} \mathrm{O}\right]$ are concentrations of $\mathrm{HCHO}$, hydronium ions and water in the drift tube. The kinetics of the HCHO detection has been discussed in detail by Vlasenko et al. (2010) 
and we only summarize here. The humidity dependent concentration of $\mathrm{HHCHO}^{+}$ion concentration in the drift tube can be described as follows:

$$
\left[\mathrm{H} \cdot \mathrm{HCHO}^{+}\right]=\left[\mathrm{H}_{3} \mathrm{O}^{+}\right] \frac{k_{\mathrm{R} 1}[\mathrm{HCHO}]\left(1-e^{-k_{\mathrm{Rla}}\left[\mathrm{H}_{2} \mathrm{O}\right] t}\right)}{k_{\mathrm{R} 1 \mathrm{a}}\left[\mathrm{H}_{2} \mathrm{O}\right]} .
$$

In Reaction (R2) the $\mathrm{H} \cdot \mathrm{HCHO}^{+}$concentration is dependent on the reaction time $t$, and at low water concentrations Reactions (R1) and (R1a) are not in equilibrium at standard PTRMS conditions (de Gouw and Warneke, 2007). This makes it clear that the detection of HCHO with PTR-MS is not only strongly humidity dependent, but also clearly less efficient than for other VOCs, where the back reaction rate coefficient is very small.

Besides the humidity dependence, the lowered sensitivity has made aircraft measurements of HCHO with PTRMS very challenging. Our PTR-MS system has undergone constant improvements over the past years resulting in substantial increases in sensitivity, which are demonstrated in Fig. 1. The sensitivities $(S / N=3)$ and detection limits of methanol, benzene and acetone during five different aircraft missions in the past eight years have steadily increased to just over $1000 \mathrm{~Hz} \mathrm{ppbv}^{-1}$ for acetone, which is a compound with one of the highest sensitivities. The improvements include (1) changing from standard PTR-MS to high sensitivity PTR-MS, which adds a pumping stage at the lens system of the quadrupole, (2) replacing the original ion source, (3) modifying the vacuum chamber to improve pumping of the quadrupole chamber and (4) the use of a different multiplier (ETP SGE 14140). The sensitivities observed here are comparable to other well-running PTR-MS systems (Jordan et al., 2009). Even at a reduced sensitivity, as expected for $\mathrm{HCHO}$, the PTR-MS in its current configuration should be able to deliver measurements at adequate quality and time response for aircraft measurements, especially in a polluted location such as the Los Angeles basin.

\subsection{Aircraft inlet and calibration set-up}

The aircraft inlet used for the PTR-MS during CalNex is shown in Fig. 2. The inlet is based on the one described previously by de Gouw and Warneke (2007) but was subsequently improved. The inlet was about a total $1.5 \mathrm{~m}$ long from the tip of the winglet to the drift tube, consisted partly out of PFA Teflon (1/8" O.D.) and PEEK (1/16" O.D.) tubing, and was temperature and pressure controlled at $75^{\circ} \mathrm{C}$ and 120 mbar. PFA Teflon has been found to transmit $\mathrm{HCHO}$ efficiently (Wert et al., 2002). Instrument background measurements are done using a catalyst made out of platinum wool at $250^{\circ} \mathrm{C}$, which was housed in the winglet sticking out of the aircraft, so that zero air (VOC and ozone free) can be generated as far forward in the sample stream as possible. Due to impurities in the catalyst that were picked up in the hangar during installations, nitric oxide (NO) was produced in the catalyst at the usual $350{ }^{\circ} \mathrm{C}$ setting. This artifact was avoided by setting the catalyst to $250^{\circ} \mathrm{C}$ during

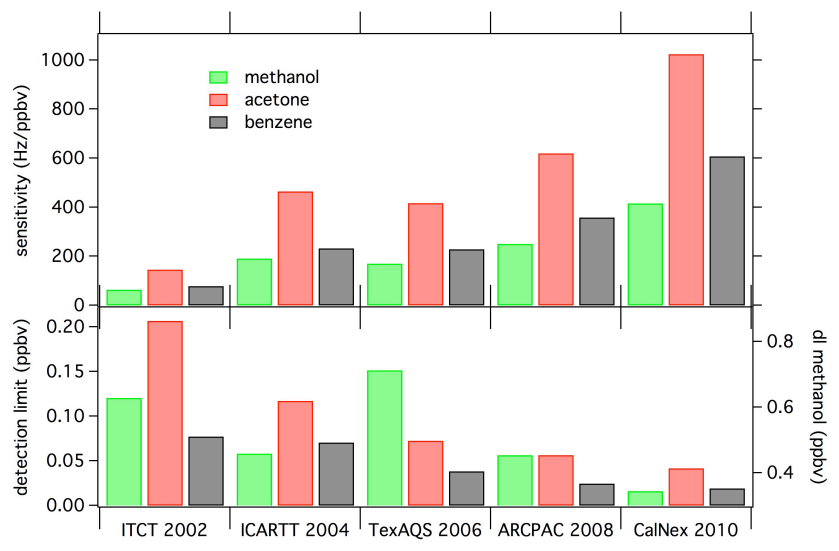

Fig. 1. The PTR-MS sensitivity and detection limits $(S / N=3)$ for methanol, benzene and acetone during five different aircraft missions during the past eight years: ITCT 2002 (de Gouw et al., 2004), ICARTT 2004 (Warneke et al., 2004), TexAQS 2006 (Warneke et al., 2010a), ARCPAC 2008 (Warneke et al., 2010b) and CalNex 2010.

the flights, which did not seem to have influenced its performance. In laboratory tests it was determined that the catalyst completely converts $\mathrm{HCHO}$ to $\mathrm{CO}_{2}$ without changing the humidity making it an ideal background measurement for HCHO PTR-MS measurements.

Aldehydes including $\mathrm{HCHO}$ are not very stable in gas cylinders and therefore a permeation source was used to calibrate the PTR-MS during the flight. The permeation tube was housed in a Teflon cylinder at constant $20 \mathrm{sccm}$ zero air flow, $50^{\circ} \mathrm{C}$ and $2 \mathrm{bar}$, which keeps the permeation rate constant throughout the flight (Fried et al., 2003; Neuman et al., 2003). The permeation oven set-up was mounted in the aircraft rack about $3 \mathrm{~h}$ before the flights and kept under the constant conditions to ensure stable output at the beginning of the flight. In between flights, the set-up was kept under the same conditions in the hangar, where it was connected to the Mobile Organic Carbon Calibration System (MOCCS) that was recently developed (Veres et al., 2010). MOCCS consists of a catalytic converter (identical to the one used for PTR-MS background measurements) that converts the VOCs in the output of the permeation oven quantitatively to $\mathrm{CO}_{2}$, which is then detected by a LiCor $\mathrm{CO}_{2}$ analyzer. The LiCor was calibrated with 2, 5, 20, and 50 ppmv gas standards to be in the same range as the permeation source output converted into $\mathrm{CO}_{2}$. The MOCCS can quantify the output of a permeation tube instantly forgoing the need to have the permeation tubes under constant conditions for very long periods of time usually months, so that the output can be determined gravimetrically. The same inlet and calibration set-up were used in the laboratory experiments conducted before CalNex as during the aircraft campaign. 


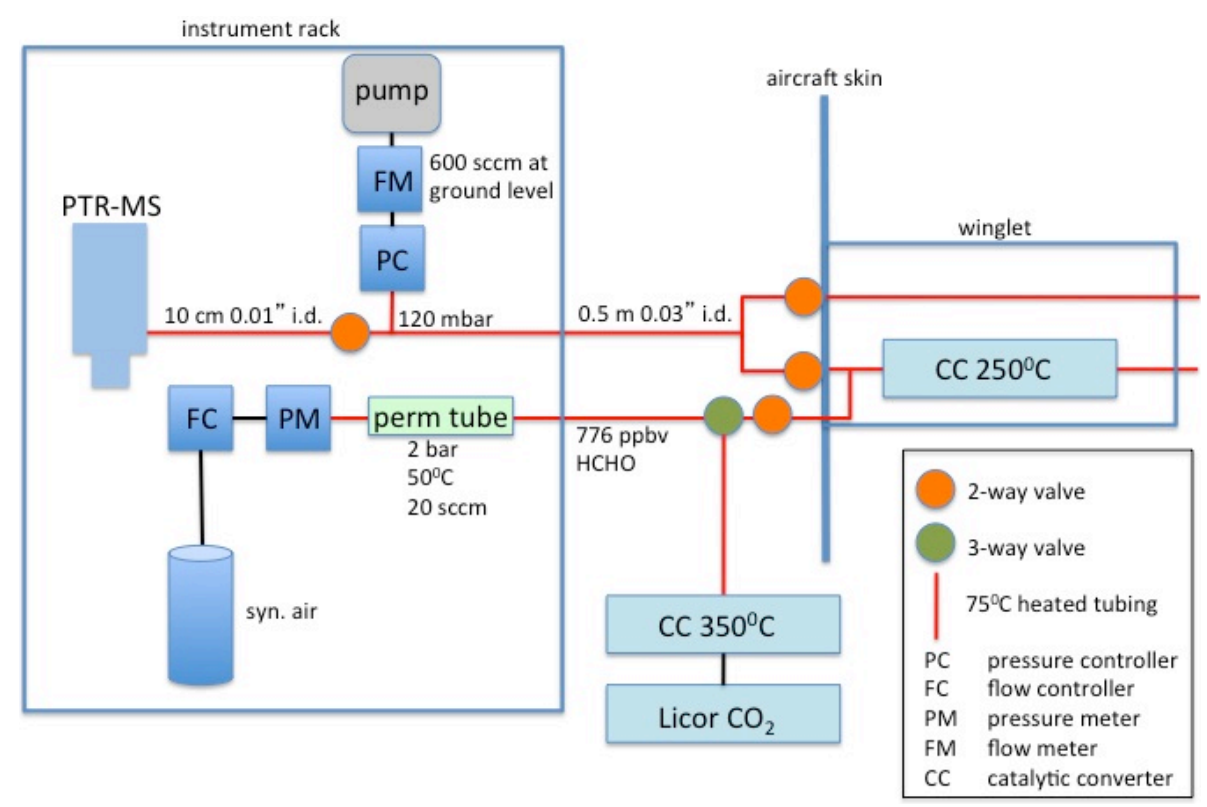

Fig. 2. Inlet and calibration system used during the CalNex 2010 campaign on the NOAA WP-3 aircraft.

\subsection{CalNex aircraft campaign}

During the CalNex campaign the NOAA WP-3 aircraft was stationed in Ontario, California during May and June 2010 and performed 20 research flights mainly over the Los Angeles (LA) basin and the Central Valley in California. The main goals of CalNex were emission quantification of greenhouse gases, ozone and aerosol precursors, the quantification of chemical transformations, and the transport of pollution. The NOAA WP-3 aircraft was equipped with a large suite of gas phase and aerosol measurements, but for this paper we only use the PTR-MS and CO data.

The Caltech/Pasadena ground site, $15 \mathrm{~km}$ northeast of downtown Los Angeles was located on a parking lot at the Caltech campus in an urban area $1.2 \mathrm{~km}$ from interstate 210. Multiple over-flights were performed during the campaign. The HCHO measurements made by PTR-MS onboard the aircraft will be compared to a DOAS instrument and a Hantzsch monitor at the ground site.

\subsection{Other instruments}

UCLA's long-path (LP) DOAS instrument (Stutz and Platt, 1997; Platt and Stutz, 2008) was located at the Pasadena ground site on the Caltech campus on the roof of the Millikan Library at $35 \mathrm{~m}$ a.g.l. (above ground level) (coordinates $34.1405,-118.122$ ). Four retro-reflectors were located northeast of the main instrument in mountains behind Altadena at $78 \mathrm{~m}$ a.g.l. (lowest; coordinates $34.17615,-118.092417$ ), at $121 \mathrm{~m}$ a.g.l. (middle; coordinates $34.1789,-118.091883$ ), at $255 \mathrm{~m}$ a.g.l. (upper; coordinates $34.190217,-118.08695$ ) and at $556 \mathrm{~m}$ a.g.l. (highest; coordinates $34.193567,-118.09215)$. The average distance between the LP-DOAS telescope and the reflectors was about $6 \mathrm{~km}$.

Spectral retrievals of $\mathrm{HCHO}$ mixing ratios were performed in the wavelength range between $324-346 \mathrm{~nm}$ using a combination of a linear and non-linear least squares fit, as described in Stutz and Platt (1996) and Alicke et al. (2002). Spectral absorption structures of $\mathrm{O}_{3}, \mathrm{NO}_{2}, \mathrm{HONO}, \mathrm{O}_{4}$, and $\mathrm{HCHO}$ were incorporated in the fitting procedure. Errors of HCHO mixing ratios were calculated as $1 \sigma$ statistical uncertainties by the analysis procedure for each individual spectrum and trace gas (Stutz and Platt, 1996). The campaign averaged statistical HCHO error during CalNex was $\sim 150$ ppt. The systematic errors of the reported trace gas mixing ratios are dominated by the uncertainties of the HCHO absorption cross sections of $\pm 5 \%$ (Meller and Moortgat, 2000). The systematic error of the DOAS spectrometer was $<3 \%$ (Platt and Stutz, 2008).

Formaldehyde was measured on the Pasadena ground site in-situ using the fluorometric Hantzsch reaction (FHR, model AL4021, http://www.aerolaser.com). FHR based $\mathrm{HCHO}$ measurement instrumentation have been extensively field-used and validated (Gilpin et al., 1997; Wisthaler et al., 2008; Cardenas et al., 2000; Hak et al., 2005; Apel et al., 2008). The University of Houston has employed this technique both at ground sites (Rappengluck et al., 2010) and in airborne science missions (Boeke et al., 2011). The inlet was a funnel located at $4 \mathrm{~m}$ from the ground attached to $5.5 \mathrm{~m}$ of PFA Teflon (0.25 in O.D.) tubing. The instrument was calibrated weekly using a working gas standard (Air Liquide America Scott Specialty Gases LLC, Plumstead, PA; 5 ppm $\mathrm{HCHO}$ in $\mathrm{N} 2$ ) and auto-zeroed every $90 \mathrm{~min}$ for $10 \mathrm{~min}$. 
During the study the gas standard cylinder was hooked up to the MOCCS (Mobile Organic Carbon Calibration System; (Veres et al., 2010) for a duration of $18.5 \mathrm{~h}$, and a HCHO concentration of $6.86 \pm 0.15 \mathrm{ppm}$ was determined. In addition, the AL4021 was calibrated on-site using a HCHO permeation tube. The limit of detection for the HCHO instrument was $60 \mathrm{pptv}$ (three times signal-to-noise ratio; $1 \mathrm{~min}$ averaging); the estimated uncertainty was $\pm 10 \%$.

Carbon monoxide (CO) was measured from the aircraft with a vacuum ultraviolet fluorescence instrument (Holloway et al., 2000). The overall uncertainty of the measurements is estimated to be about $5 \%$ with a $2 \sigma$ detection limit of about 1 ppbv.

Acetaldehyde was measured on the ground site using an in-situ gas chromatograph equipped with a mass spectrometer (GC-MS) and a Proton-transfer Ion Trap Mass Spectrometer (PIT-MS), which is an instrument similar to a PTRMS. Instrumental details on the two instruments can be found elsewhere (Gilman et al., 2010; Warneke et al., 2005).

\section{Instrument characterization}

\subsection{Interference test with GC-PTR-MS}

Before the PTR-MS can be calibrated for $\mathrm{HCHO}$ on mass 31, it needs to be determined, if mass 31 is free of interferences. Fragmentation from larger compounds are the most probably source of interferences on mass 31 . Inomata et al. (2008) have found small interferences from methyl hydroperoxide $\left(\mathrm{CH}_{3} \mathrm{OOH}\right)$ and fragments of methanol and ethanol. In ambient air, the concentration of methyl hydroperoxide is expected to be very small compared to HCHO, so any associated interferences will be negligible.

Before the CalNex 2010 campaign we tested the PTRMS for interferences in the laboratory using GC-PTR-MS (Warneke et al., 2003). The basic principle is that a gas chromatographic (GC) column is used to pre-separate VOCs by their retention time before they are detected with PTR-MS. Any interferences on mass 31 will appear as distinct chromatographic peaks corresponding to the retention time of the parent compound. Various calibration standards containing a large number of VOCs, including methanol and ethanol, as well as ambient air samples with or without a standard addition of HCHO were tested with GC-PTR-MS to look for peaks on mass 31 in the chromatograms. HCHO was detected non-quantitatively with GC-PTR-MS on mass 31 , but no other signal was detected on that mass. Formic and acetic acid that are not detectable with GC-PTR-MS were tested separately using PTR-MS without the GC front-end and no interferences were found. This shows that the minimum requirements of no substantial interferences for successful HCHO measurements with PTR-MS are most likely fulfilled.
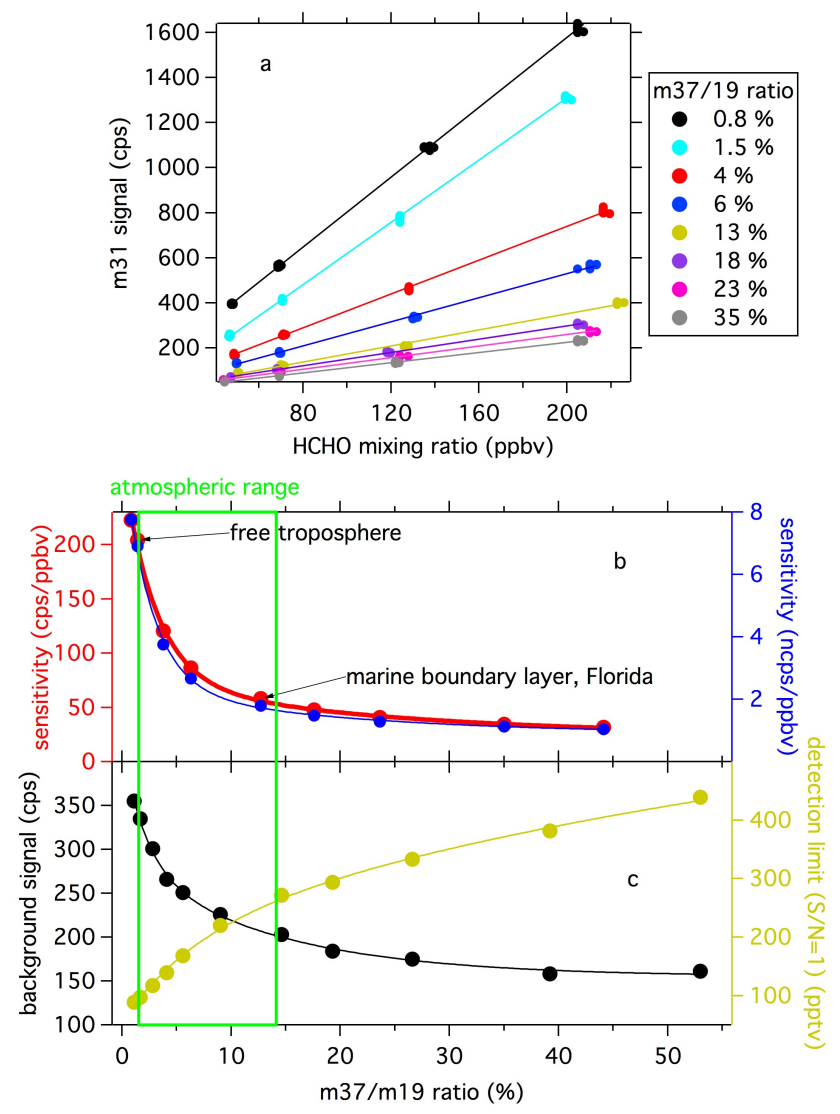

Fig. 3. (a) Calibration curves of the PTR-MS mass 31 versus HCHO mixing ratio (ppbv) at different humidities. (b) Sensitivity for HCHO dependent on the humidity. (c) The background signal and the detection limit for $\mathrm{HCHO}$ dependent on the humidity.

\subsection{Laboratory calibration}

Laboratory calibrations with $\mathrm{HCHO}$ were performed before CalNex using the aircraft inlet and the permeation tube setup at different humidities. In Fig. 3a the PTR-MS signal on mass 31 is plotted versus the mixing ratio of HCHO generated by diluting the permeation tube output in synthetic air humidified to various degrees. Each line represents a separate calibration curve at a different humidity. In the PTR-MS reaction chamber ambient water vapor and water vapor from the ion source add up to determine the $\mathrm{H}_{2} \mathrm{O}$ mixing ratio in Reaction (R1) (Warneke et al., 2001; Vlasenko et al., 2010), which determines the measured distribution of the $\mathrm{H}_{3} \mathrm{O}^{+}$ (mass 19) and $\mathrm{H}_{3} \mathrm{O}^{+} \cdot \mathrm{H}_{2} \mathrm{O}$ (mass 37 ) ions (Warneke et al., 2001). Here it should be mentioned that we actually monitor the natural isotopes of $\mathrm{H}_{3} \mathrm{O}^{+}$and $\mathrm{H}_{3} \mathrm{O}^{+} \cdot \mathrm{H}_{2} \mathrm{O}$ on masses 21 and 39 and calculate masses 19 and 37, because the number of ions on those masses are too high to quantitatively count them. In Fig. 3a the calibration curves are color coded with the mass 37/mass 19 ratio instead of the water mixing ratio, because this ratio is (1) directly related to Reaction (R2), (2) measured by the PTR-MS simultaneously with $\mathrm{HCHO}$ on 
mass 31 , and (3) takes the amount of $\mathrm{H}_{3} \mathrm{O}^{+}$primary ions into account. The relationship between the mass $37 /$ mass 19 ratio and the ambient water concentration is shown in Fig. 4. The data shown in Fig. 4 were taken during one research flight during CalNex and include data from the marine boundary layer off shore from the Los Angeles Basin and the free troposphere. This ambient measurement had mass 37/mass 19 ratios between $1-10 \%$.

In Fig. $3 b$ the sensitivity of the PTR-MS towards HCHO (the slope from the calibration curves in Fig. 3a) is plotted versus the mass $37 /$ mass 19 ratio. The atmospheric range observed during CalNex is indicated in Fig. 3b showing that the sensitivity ranged from $200 \mathrm{~Hz} \mathrm{ppv}^{-1}$ in the free troposphere to around $60 \mathrm{~Hz} \mathrm{ppbv}^{-1}$ in the marine boundary layer. This is clearly lower than all other compounds that are usually between $400 \mathrm{~Hz} \mathrm{ppbv}^{-1}$ (methanol) and $1000 \mathrm{~Hz} \mathrm{ppbv}^{-1}$ (acetone), as shown in Fig. 1. During CalNex 2010 the primary ion signal of the PTR-MS was around $30 \times 10^{6} \mathrm{~Hz}$ so that the range of the HCHO sensitivity normalized to the primary ion signal was about $2-7 \mathrm{ncps} \mathrm{ppbv}^{-1}$ (also shown in Fig. 3b) and methanol and acetone were around $13.3 \mathrm{ncpspbv}^{-1}$ and $33.3 \mathrm{ncpsppv}^{-1}$, respectively. The sensitivity for $\mathrm{HCHO}$ is in the range of other VOCs during previous successful aircraft missions (see Fig. 1). A similar calibration curve and all the kinetic equations to calculate the humidity dependence of HCHO in the PTR-MS reaction chamber can be found in Vlasenko et al. (2010).

The detection limit is not only determined by the sensitivity, but also by the instrument background. Figure $3 \mathrm{c}$ shows the background measurements for mass 31 using the catalytic converter in the PTR-MS. The results in Fig. 3c are from laboratory measurements, but the instrument background was comparable during the aircraft mission. The instrument background changes with the mass $37 /$ mass 19 ratio similarly as the sensitivity, but does not drop as fast. $\mathrm{NO}^{+}$ on mass 30 is produced in the ion source and the natural isotope from $\mathrm{NO}^{+}$contributes about $50-100 \mathrm{~Hz}$ to the signal on mass 31 . The $\mathrm{NO}^{+}$signal is strongly dependent on the ion source setting and the humidity, but this signal alone cannot explain the entire background signal on mass 31 . The detection limit is calculated from the noise on the background (square root of the count rate; de Gouw and Warneke, 2007) on mass 31 and the sensitivity for HCHO. Figure 3c shows that the limits of detection at a conservative signal-to-noise of three $(S / N=3)$ ranged from 300 pptv in dry to $900 \mathrm{pptv}$ in humid atmospheric conditions.

This means that in the free troposphere or clean marine boundary layer 1-s measurements are challenging and some averaging should be applied, but in more polluted regions 1-s measurements are possible. Looking at previous campaigns and the earlier sensitivity of the PTR-MS (Fig. 1), the detection limit for HCHO for example during ICARTT2004 was roughly between $600 \mathrm{pptv}$ and $1800 \mathrm{pptv}$. At such detection limits, aircraft measurements become difficult without long averaging times.

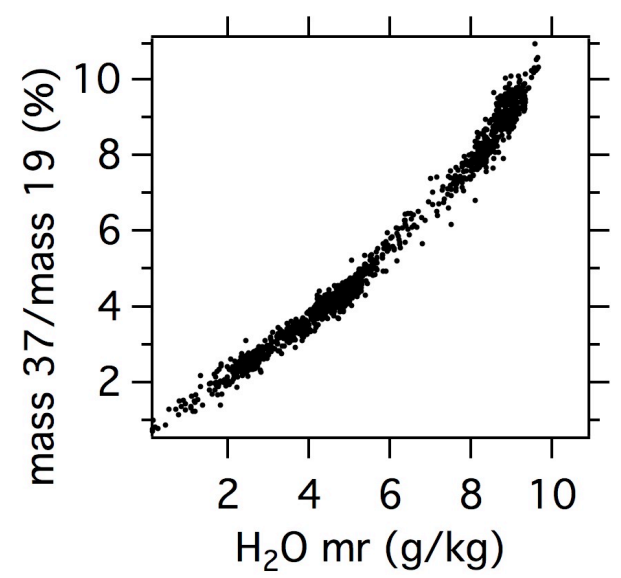

Fig. 4. The ratio of $\mathrm{H}_{3} \mathrm{OH}_{2} \mathrm{O}^{+} / \mathrm{H}_{3} \mathrm{O}^{+}$(mass 37/mass 19) versus the ambient water mixing ratio (i.e. humidity) for a typical flight during CalNex 2010.

\subsection{In-flight calibration}

In-flight calibrations were performed during three separate research flights on 20 April, 21 April and 18 June 2010. The constant output of the HCHO permeation source was diluted into the inlet flow that varied from about $100 \mathrm{sccm}$ at the highest flight altitude to about $600 \mathrm{sccm}$ in the boundary layer. The results of the in-flight calibrations from all three flights are shown in Fig. 5a, where the background subtracted signal on mass 31 is plotted versus the inlet flow. Because of the humidity dependence, which is indicated with the color code in Fig. 5a, the observed signal is not linear with the inlet flow. As mentioned above, the inlet flow is altitude dependent and generally in the atmosphere so is the humidity. The in-flight humidity dependence is compared to the one determined in the laboratory in Fig. 5b, where the calibrations factors are plotted versus the mass 37/mass 19 ratio. In-flight calibrations are less accurate than laboratory measurements due to the short amount of time that can be afforded on calibrations during the flight and due to the high concentrations of the calibration during the high altitude flight legs. Nevertheless the pre- and in-flight calibrations agreed to within $30 \%$. We assume that the instrument sensitivity does not change in-flight by $30 \%$, only that the in-flight calibration is less accurate. The calibrations performed on the ground during the campaign agreed with the ones from before and after the campaign performed in the laboratory to within $10 \%$ and the combined estimated uncertainty for the calibration is $30 \%$ and therefore the accuracy of the instrument during flights is also $30 \%$ and independent of the mixing ratios.

The determination of the $\mathrm{HCHO}$ calibration factor for all flights during CalNex 2010 was done using the fit shown in Fig. $5 \mathrm{~b}$ with the solid red line, which is the laboratory calibration. Vlasenko et al. (2010) already noted that Eq. (2) does not describe the calibration data perfectly, especially at 

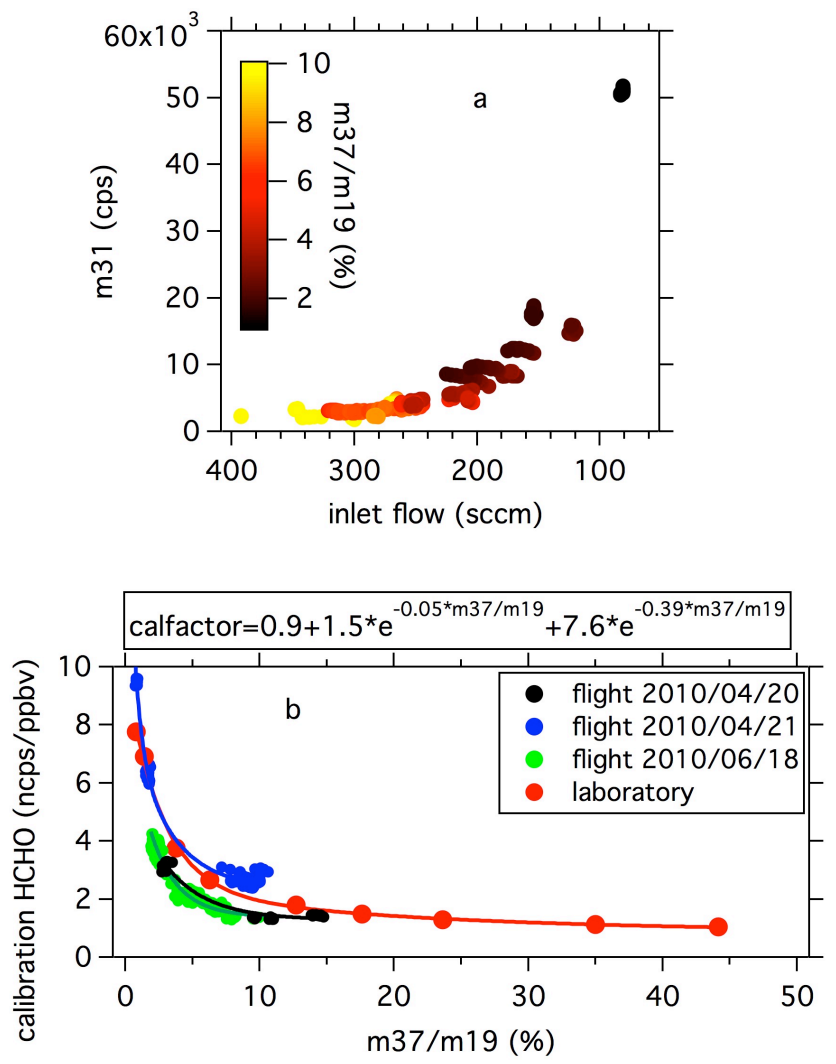

Fig. 5. (a) Background subtracted raw signals from the in-flight calibration of the PTR-MS for HCHO during flights on 20 April, 21 April and 18 June 2010 versus the inlet flow, which is proportional to the altitude. The color code represents the humidity (equivalent to the mass 37/mass 19 ratio). (b) Laboratory and in-flight calibration of the PTR-MS for HCHO dependent on the humidity. A double exponential fit is used to describe the humidity dependence of the PTR-MS HCHO sensitivity.

high humidity. One explanation is that the ligand switching reactions of the protonated water dimers also produces protonated $\mathrm{HCHO}$ after collisional dissociation of the $\mathrm{HCHO}$ water cluster (Jobson and McCoskey, 2010). Therefore the best fit to the calibration data in Fig. 5b is a double exponential fit. The expression we used to calculate the HCHO calibration factor for all flights is also given in Fig. 5b.

The precision of the PTR-MS for HCHO during the flights can be determined from the standard deviation of constant mixing ratios during the in-flight calibrations or from the ion counting statistics. The precision is reciprocal to the standard deviation (or noise), which is the square root of the signal in $\mathrm{Hz}$ in PTR-MS; the relative noise decreases with increasing mixing ratios and relatively the precision improves (de Gouw and Warneke, 2007). In Fig. 6 the mixing ratio dependent noise of HCHO is compared to methanol, benzene and acetone. The data in Fig. 6 are calculated from the counting statistics using typical instrument backgrounds and sensitivities observed during CalNex 2010. Standard deviations from

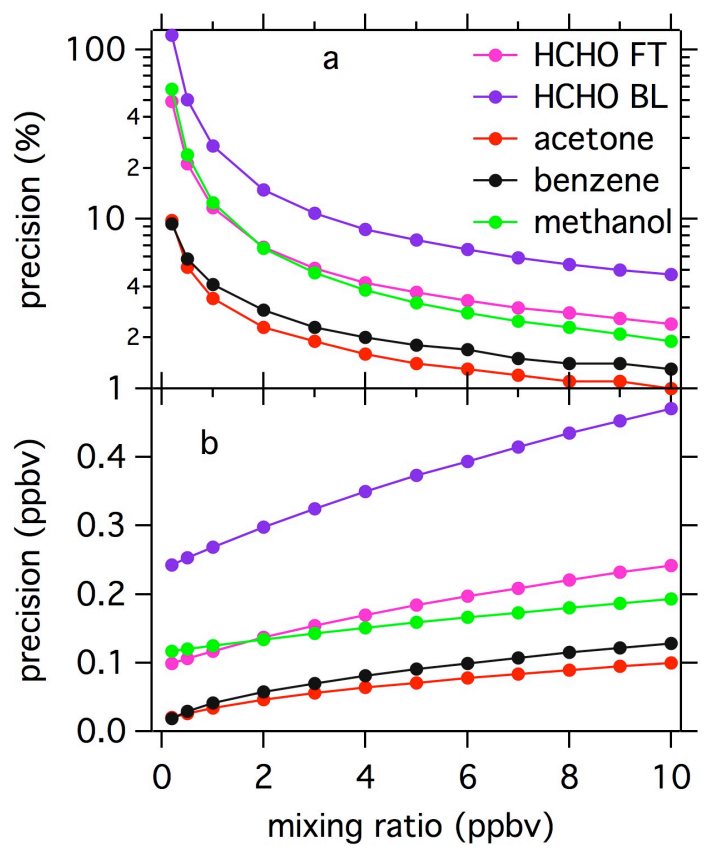

Fig. 6. The noise calculated from counting statistics of the PTRMS for HCHO in the free troposphere (FT) and the boundary layer (BL) together with methanol, acetone and benzene for typical backgrounds and sensitivities observed during CalNex 2010: (a) in percent as relative noise, (b) in ppbv as absolute noise.

various calibration measurements, including the $\mathrm{HCHO}$ inflight calibrations, were used to confirm the results, but are not shown here. The HCHO background and the sensitivity are both humidity dependent and therefore the precision at the same mixing ratios in the free troposphere is better than in the boundary layer, but not as good as for other compounds measured by PTR-MS. The HCHO noise ranges from over $100 \%$ at $200 \mathrm{pptv}$ in the boundary layer, which is actually below the detection limit, to below $3 \%$ at $10 \mathrm{ppbv}$ in the free troposphere. The calculation of the noise assumes that for each data point the background is well known, which is generally the case for compounds where the background during the flight is very small or does not change such as benzene or acetone. For HCHO, where the background is variable, the precision deteriorates due to the uncertainty in the background determination. The HCHO background, determined with high precision by averaging five individual data points, is varying with the humidity. As will be discussed below, the variation is very well defined using PTR-MS signals on masses 19, 37 and 31. The precision of the instrument can be improved by longer averaging times, but variations in the background cannot be improved in this way. This means that the data in Fig. 6 represent only lower limits for the noise of the PTR-MS, but for typical mixing ratios as encountered during the flights the counting statistics dominates the precision. 


\section{Airborne results}

\subsection{Example flight}

Here we demonstrate how the HCHO mixing ratio was determined from the raw PTR-MS data during CalNex 2010 using an example flight on 19 May 2010. This flight was chosen, because it covered very different humidity conditions and pollution levels with flight tracks in the LA basin, off shore in the marine boundary layer, at high altitudes and over the high desert outside the basin.

The raw data (m31), background (bg31) and ambient signal (raw data - background signal $=$ ambient signal) are shown in Fig. 7a all normalized to the primary ion signal. From looking at the raw data it is clear that the PTR-MS HCHO detection does not only suffer from low and humidity dependent sensitivity, but also from high and humidity dependent background signals. The background was measured every $12 \mathrm{~min}$ and therefore has to be interpolated for subtraction from the ambient data. Due to the fast changes in humidity during flights a linear interpolation of the background data is not suitable. In Fig. 3c we already showed the humidity dependence of the mass 31 background signal. In Fig. $7 \mathrm{~b}$ the mass 31 background signal is plotted against the mass $37 /$ mass 19 ratio for this flight. The fit of this curve, shown with the yellow line in Fig. $7 \mathrm{~b}$, is used to calculate the background on mass 31 for the whole flight. The result is shown in Fig. 7a as a yellow line that connects the individual background measurements. The background is subtracted from the signal and the result is shown in Fig. 7a with the blue line.

The calibration factor is determined in Fig. 7c. The calibration factor is calculated as discussed earlier from the mass 37/mass 19 ratio using the fit and the expression given in Fig. 5b. The ambient mixing ratio is calculated in Fig. 7d by dividing the background-subtracted signal (blue line in Fig. 7a) by the calibration factor (red line in Fig. 7c). The mixing ratio is shown as a three point running average from the 1-s data (every $16 \mathrm{~s}$ ).

$\mathrm{CO}$ as an anthropogenic tracer is also shown in Fig. 7d. It is very clear that the HCHO mixing ratio is very well correlated with $\mathrm{CO}$ throughout the flight even in the free troposphere, where small changes in $\mathrm{CO}$ are tracked by $\mathrm{HCHO}$.

\subsection{Inter-comparison}

Various over-flights during day and nighttime were performed for inter-comparison purposes over the ground site located in Pasadena. The aircraft flight altitude for all the over-flights was between $250 \mathrm{~m}$ and $500 \mathrm{~m}$ a.g.l. The time series of the DOAS light paths at four different heights (from $35 \mathrm{~m}$ in Pasadena to $78 \mathrm{~m}, 121 \mathrm{~m}, 255 \mathrm{~m}$, and $556 \mathrm{~m}$ at the reflectors) and the data from the Hantzsch monitor at the surface are shown in Fig. 8a together with he PTR-MS data averaged over a $10 \mathrm{~km}$ stretch around the ground site.

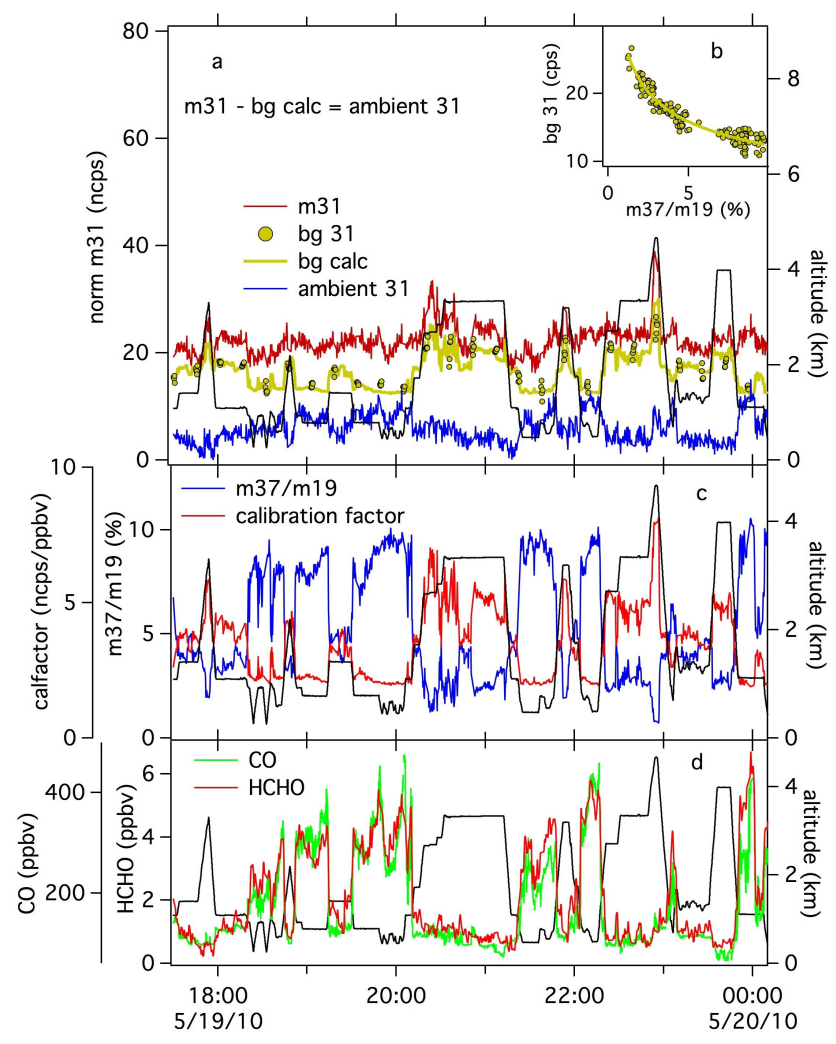

Fig. 7. Example flight on 19 May 2010 during CalNex 2010. (a) Raw signals (ambient and instrument backgrounds) of $\mathrm{HCHO}$ during the flight. (b) Humidity dependence of the instrument background signal. (c) Calibration factor estimated from the mass 37/mass 19 ratio. (d) $\mathrm{HCHO}$ mixing ratio together with $\mathrm{CO}$.

A scatter plot of the DOAS data versus the Hantzsch monitor and the PTR-MS over-flights is given in Fig. 8b. This inter-comparison features measurements from an aircraft (PTR-MS), from an instrument that gives a long-path regional average (DOAS) and from the ground (Hantzsch) and therefore local differences in mixing ratios will influence the inter-comparison. There are two other complicating factors: (1) The DOAS switches between the different elevation angles, which results in long time gaps between data points at the same elevation angle. The nearest data point, regardless of elevation angle, was used in the scatter plot in Fig. 8b. (2) During the nighttime flights, the aircraft usually did not get low enough into the nighttime surface layer and therefore the values at the ground are not representative of the values aloft. This is clearly demonstrated in Fig. 8c, which shows the inter-comparison of acetaldehyde from the aircraft PTR-MS measurements with the results from the ground-site using the GC-MS and the PIT-MS data. For acetaldehyde the daytime over-flights agree well within the measurement uncertainties with the ground site measurements (slope of 0.80 and $R=0.87$ ), but the nighttime mixing ratios are clearly lower aloft. On some nights, the higher elevation angles of 


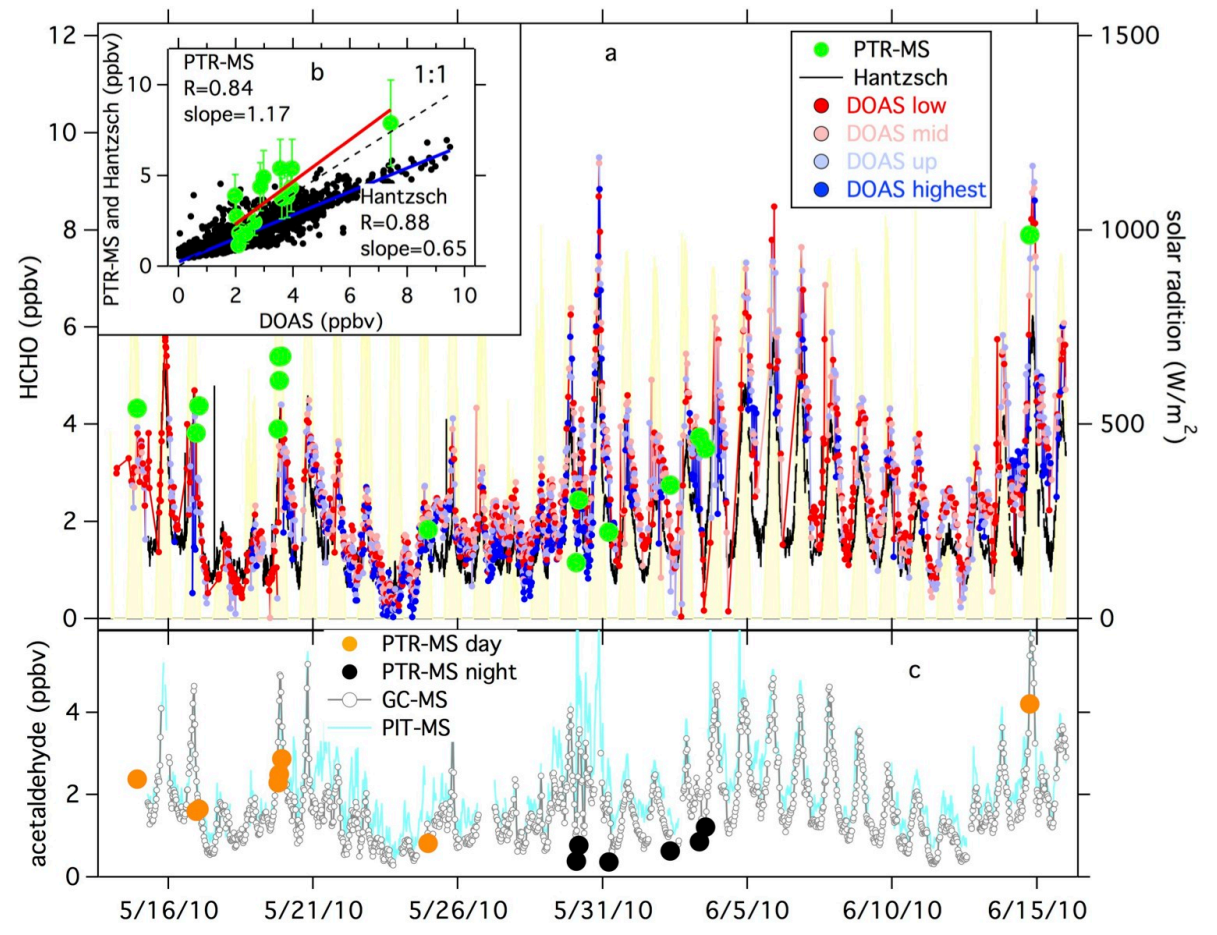

Fig. 8. (a) Inter-comparison of the airborne PTR-MS HCHO with measurements using a DOAS and a Hantzsch monitor at the Pasadena ground site. (b) Scatter plot of the PTR-MS and the Hantzsch versus the DOAS HCHO measurements. Error bars of the PTR-MS measurements are the accuracy of each data point. (c) Inter-comparison of the airborne PTR-MS acetaldehyde with measurements using a GC-MS and a PIT-MS on the Pasadena ground site. The color code of the aircraft data indicates the day- and nighttime measurements.

the DOAS show lower mixing ratios than the lower angels indicating that they might be more representative of the air mass sampled by the aircraft.

Despite all these complications, all over-flights were included in the inter-comparison. The slope of the scatter plot shows that the PTR-MS is about $10 \%$ higher than the DOAS, which is in turn about $35 \%$ higher than the Hantzsch monitor. This means that the PTR-MS (accuracy 30\%) agrees well within the stated uncertainties with the DOAS (accuracy $5 \%$ ) and just outside the stated uncertainties with the Hantzsch monitor (accuracy 10\%). The agreement especially with the DOAS instrument gives further confidence in the validity of the aircraft PTR-MS HCHO measurements.

\subsection{HCHO enhancement ratios in the LA plume and comparison with other data sets}

Scatter plots of $\mathrm{HCHO}$ versus acetaldehyde and versus $\mathrm{CO}$ for the example flight on 19 May 2010 are shown in Fig. 9. Linear fits for all the data in the LA basin and the free troposphere are used to calculate the enhancement ratios $\Delta \mathrm{HCHO} / \Delta \mathrm{CO}$ and $\Delta \mathrm{HCHO} / \Delta$ acetaldehyde. The Los Angeles basin is characterized by a mixture of re-circulated aged air and fresh anthropogenic emissions from a large variety of different sources such as vehicular and industrial emissions. An overall enhancement ratio of $12 \mathrm{pptv}_{\mathrm{ppbv}}{ }^{-1}$ for $\Delta \mathrm{HCHO} / \triangle \mathrm{CO}$ and $1.5 \mathrm{ppbv}_{\mathrm{ppbv}}{ }^{-1}$ for $\Delta \mathrm{HCHO} / \Delta$ acetaldehyde was found in the LA basin for this flight. The free troposphere encountered during this flight was certainly impacted by aged pollution, which can be seen in the $\mathrm{CO}$ mixing ratios of up to $250 \mathrm{ppbv}$. Secondary production of HCHO resulted in a higher enhancement ratio of $\Delta \mathrm{HCHO} / \Delta \mathrm{CO}$ with $21 \mathrm{pptv}_{\mathrm{ppbv}}^{-1}$ and of $\Delta \mathrm{HCHO} / \Delta$ acetaldehyde ratio with $3 \mathrm{ppbv}^{\mathrm{ppbv}}{ }^{-1}$. Acetaldehyde also has large secondary sources (de Gouw et al., 2005), but a shorter lifetime than $\mathrm{HCHO}$ resulting in the observed increase of their ratio. The observations of CalNex can be compared to other data sets some of which are summarized by Herndon et al. (2007), who showed $\Delta \mathrm{HCHO} / \Delta \mathrm{CO}$ ratios ranging from 2-3 pptv ppbv ${ }^{-1}$ for fresh emissions of light duty vehicles up to $50 \mathrm{pptv}^{\mathrm{ppbv}}{ }^{-1}$ for very aged air masses. Over-flights of various US cities showed ratios between 10 $25 \mathrm{pptv}_{\mathrm{ppbv}}{ }^{-1}$. In the same publication $\Delta \mathrm{HCHO} / \Delta$ acetaldehyde ratios ranging from $1 \mathrm{ppbv} \mathrm{ppbv}^{-1}$ for light duty vehicles up to $7 \mathrm{ppbv} \mathrm{ppbv}^{-1}$ for the aged air were observed. Over-flights of various US cities showed ratios between 2 $3 \mathrm{ppbv} \mathrm{ppbv}^{-1}$. The enhancement ratios observed during CalNex using the PTR-MS therefore agree well with the expected values from the literature. 

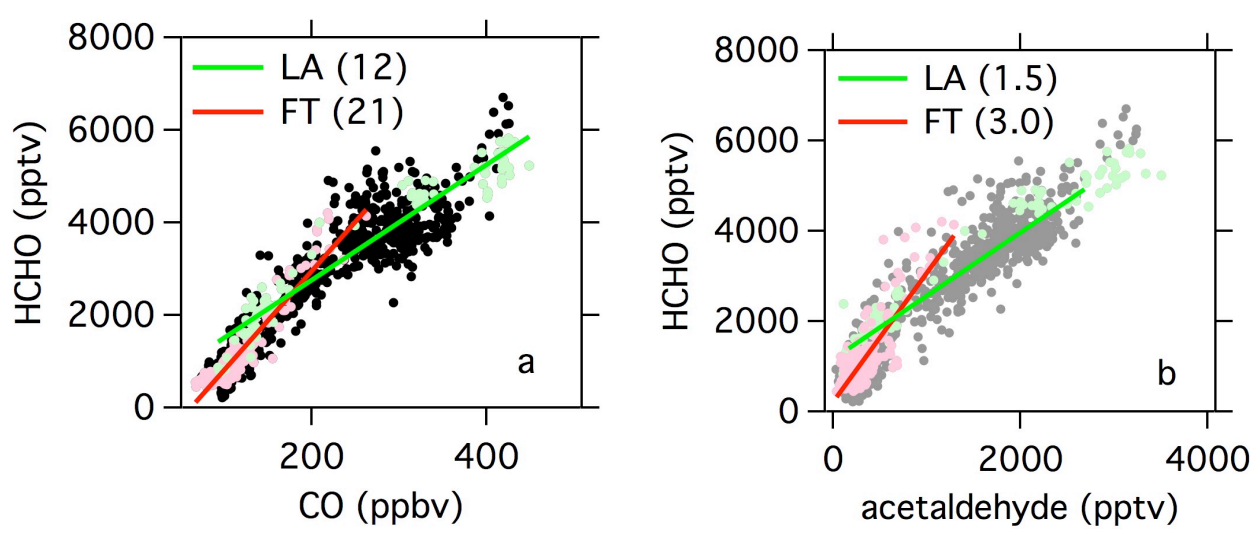

Fig. 9. Scatter plots of HCHO versus acetaldehyde and CO from a flight on 19 May 2010 in and around the Los Angeles basin including linear fits of data in the boundary layer over LA and in the free troposphere (FT). The values in the brackets are the slopes of the regression lines (in units of $\mathrm{pptv} p p b v^{-1}$ for CO and $\mathrm{pptv}_{\mathrm{pptv}}{ }^{-1}$ for acetaldehyde).

\subsection{HCHO production in an anthropogenic plume}

In this section we demonstrate the usefulness of the airborne PTR-MS HCHO measurements for a field mission by looking at the photochemical production of $\mathrm{HCHO}$ and acetaldehyde in a pollution plume. On 12 May 2010 the NOAA WP-3 aircraft followed an isolated urban plume down the Central Valley. The flight track, shown in Fig. 10a, is color-coded with the HCHO mixing ratio and the plume intersects are marked with numbers. The flight also included transects over San Francisco, which are marked with numbers 1 and 2 to give a starting point in the plume evolution. In the Central Valley the wind speed was very constant at about $7 \mathrm{~m} \mathrm{~s}^{-1}$. The plume crossings were about $25 \mathrm{~km}$ apart and therefore the transport time between transects 3-7 was about one hour each. The observed mixing ratios in the plume were rather small and therefore challenging the instrument more than the measurements in the LA plume that were presented above.

Aromatic hydrocarbons, such as benzene, toluene and C8aromatics, are emitted mainly by vehicle exhaust with certain ratios in an urban environment (Warneke et al., 2007). With plume age the toluene/benzene and $\mathrm{C} 8$-aromatics/benzene ratios decrease because of the shorter lifetimes of toluene and the C8-aromatics compared to benzene. $\mathrm{HCHO}$ and acetaldehyde have small primary emissions (Garcia et al., 2006; Ban-Weiss et al., 2008) and are produced in the plume, which causes their ratio with $\mathrm{CO}$ to increase with plume age. Figure $10 \mathrm{~b}$ shows the scatter plot of $\mathrm{HCHO}$ versus $\mathrm{CO}$ for this flight. Each plume crossing is shown with a separate color. The slopes from the scatter plot are shown in Fig. 10c together with the aromatics ratios that were determined in the same way. The aromatics ratios decrease until there are almost no detectable $\mathrm{C} 8$-aromatics in the plume. The $\mathrm{HCHO} / \mathrm{CO}$ increases throughout the plume evolution, whereas the $\mathrm{CH}_{3} \mathrm{CHO} / \mathrm{CO}$ ratio initially increases and then decreases again, when the loss of acetaldehyde due to reactions with $\mathrm{OH}$ becomes more important than the photochemical production (de Gouw et al., 2005). This example shows the net photochemical production of $\mathrm{HCHO}$ from anthropogenic emissions.

Comparing those two photochemical clocks that were determined for an anthropogenic plume with low mixing ratios shows the ability of the PTR-MS to make accurate measurements of HCHO with a high time resolution onboard an aircraft together with many other VOCs.

\section{Conclusions}

In this paper we demonstrate fast time response measurements of HCHO from an aircraft using a PTR-MS instrument that was operated at standard instrument settings to detect its usual set of compounds including various oxygenated, biogenic and anthropogenic VOCs. HCHO was measured $1 \mathrm{~s}$ every $16 \mathrm{~s}$. Aircraft HCHO measurements were made possible because of the recent improvements in the sensitivity of PTR-MS and by developing a specific calibration capability for HCHO. The humidity dependence of the PTR-MS HCHO detection was determined in the laboratory and agreed within $10 \%$ with in-flight calibrations. The sensitivity of the PTRMS for a 1-s measurement during the flights in the free troposphere was about $200 \mathrm{~Hz} \mathrm{ppbv}^{-1}$ and in the boundary layer about $60 \mathrm{~Hz} \mathrm{ppbv}^{-1}$ resulting in a detection limit $(S / N=1)$ of about $100 \mathrm{pptv}$ and $300 \mathrm{pptv}$, respectively. The HCHO sensitivity is about $5-20 \%$ of most other compounds detected by PTR-MS. Inter-comparisons with ground-based measurements and comparisons with other data sets validated the PTR-MS HCHO measurements. The usefulness of the PTR-MS measurements of HCHO together with many other VOCS is demonstrated by observing the photochemical processing in an anthropogenic plume. This study shows that PTR-MS is very likely capable of reliable HCHO measurements on-board an aircraft, but more inter-comparisons in rapidly changing conditions are still necessary. 


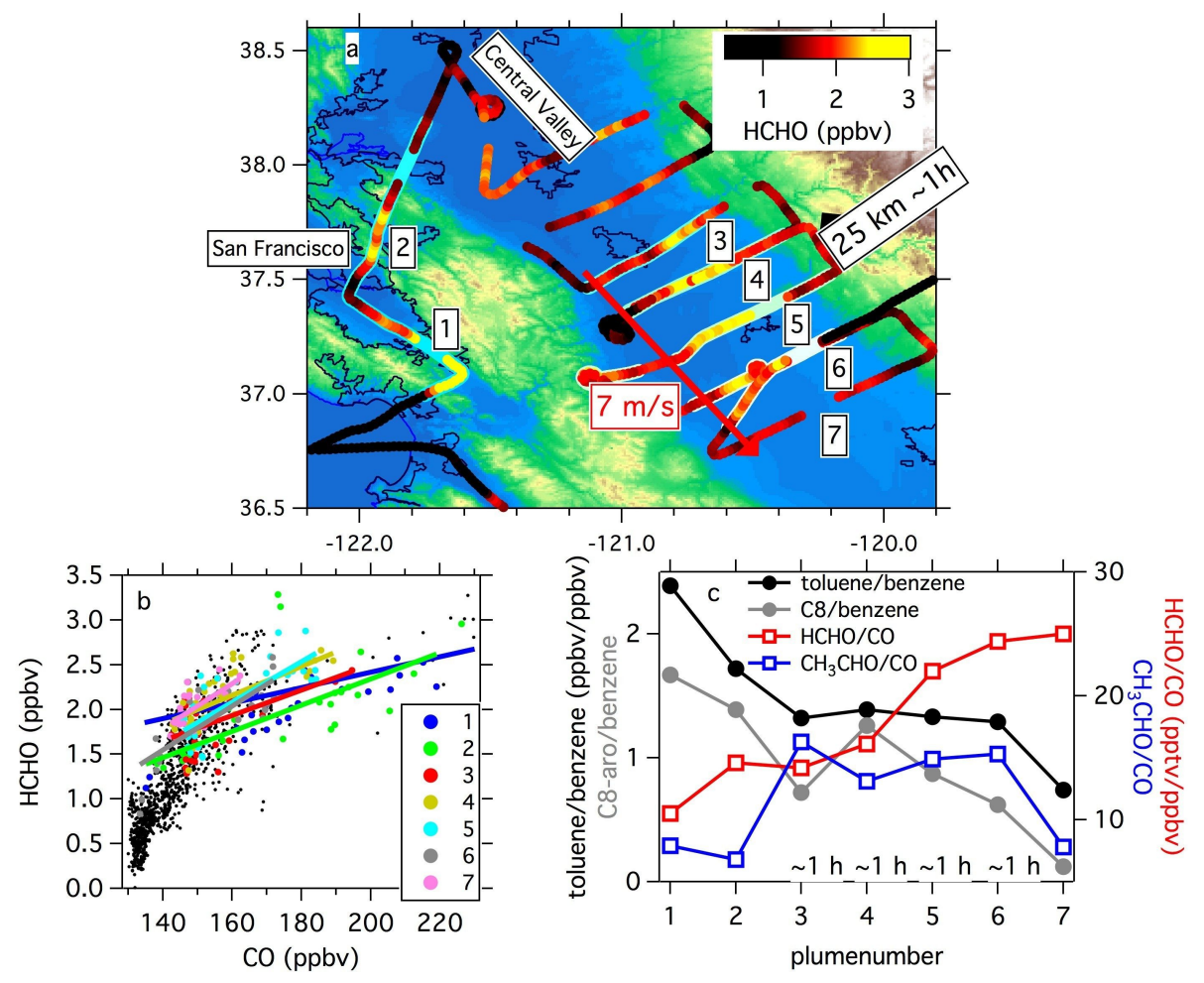

Fig. 10. (a) A map of the Central Valley with the flight track of the NOAA WP-3, which has been color coded by the HCHO mixing ratio. (b) Scatter plot of $\mathrm{HCHO}$ versus $\mathrm{CO}$ with individual plume crossings indicated in different colors. The linear fits for the individual plume crossings are also shown. (c) The increase of the $\mathrm{HCHO} / \mathrm{CO}$ and $\mathrm{CH}_{3} \mathrm{CHO} / \mathrm{CO}$ ratios - slopes of the linear fits in (b) - together with the simultaneous decrease in toluene/benzene and $\mathrm{C} 8$-aromatics/benzene ratios during the processing of the anthropogenic plume travelling down the Central Valley.

The sensitivity of the HCHO detection with PTR-MS can be improved by using different instrument set-ups, which might influence the detection of other compounds. Dependent on the goal of the measurements an optimum setting can be used. Overall, the HCHO measurements are a very useful addition to the suite of compounds usually measured with PTR-MS. In many air quality studies, including aircraft missions, PTR-MS instruments are used and careful instrument calibrations and consideration of the humidity dependence can provide fast time response $\mathrm{HCHO}$ measurements.

Acknowledgements. The NOAA Climate Change and Air Quality programs supported this work. We would like to thank crew of the NOAA WP-3 aircraft.

Edited by: D. Heard

\section{References}

Alicke, B., Platt, U., and Stutz, J.: Impact of nitrous acid photolysis on the total hydroxyl radical budget during the Limitation of Oxidant Production/Pianura Padana Produzione di Ozono study in Milan, J. Geophys. Res.-Atmos., 107, 8196, doi:10.1029/2000jd000075, 2002.

Apel, E. C., Brauers, T., Koppmann, R., Bandowe, B., Bossmeyer, J., Holzke, C., Tillmann, R., Wahner, A., Wegener, R., Brunner, A., Jocher, M., Ruuskanen, T., Spirig, C., Steigner, D., Steinbrecher, R., Alvarez, E. G., Muller, K., Burrows, J. P., Schade, G., Solomon, S. J., Ladstatter-Weissenmayer, A., Simmonds, P., Young, D., Hopkins, J. R., Lewis, A. C., Legreid, G., Reimann, S., Hansel, A., Wisthaler, A., Blake, R. S., Ellis, A. M., Monks, P. S., and Wyche, K. P.: Intercomparison of oxygenated volatile organic compound measurements at the SAPHIR atmosphere simulation chamber, J. Geophys. Res.-Atmos., 113, D20307, doi:10.1029/2008jd009865, 2008.

Ban-Weiss, G. A., McLaughlin, J. P., Harley, R. A., Kean, A. J., Grosjean, E., and Grosjean, D.: Carbonyl and nitrogen dioxide emissions from gasoline- and diesel-powered motor vehicles, Environ. Sci. Technol., 42, 3944-3950, doi:10.1021/es8002487, 2008. 
Boeke, N. L., Marshall, J. D., Alvarez, S., Chance, K. V., Fried, A., Kurosu, T. P., Rappengluck, B., Richter, D., Walega, J., Weibring, P., and Millet, D. B.: Formaldehyde columns from the Ozone Monitoring Instrument: Urban versus background levels and evaluation using aircraft data and a global model, J. Geophys. Res.-Atmos., 116, D05303, doi:10.1029/2010jd014870, 2011.

Cardenas, L. M., Brassington, D. J., Allan, B. J., Coe, H., Alicke, B., Platt, U., Wilson, K. M., Plane, J. M. C., and Penkett, S. A.: Intercomparison of formaldehyde measurements in clean and polluted atmospheres, J. Atmos. Chem., 37, 53-80, 2000.

Dasgupta, P. K., Li, J. Z., Zhang, G. F., Luke, W. T., McClenny, W. A., Stutz, J., and Fried, A.: Summertime ambient formaldehyde in five US metropolitan areas: Nashville, Atlanta, Houston, Philadelphia, and Tampa, Environ. Sci. Technol., 39, 4767-4783, doi:10.1021/es048327d, 2005.

de Gouw, J. and Warneke, C.: Measurements of volatile organic compounds in the earths atmosphere using proton-transferreaction mass spectrometry, Mass Spectrom. Rev., 26, 223-257, 2007.

de Gouw, J. A., Cooper, O. R., Warneke, C., Hudson, P. K., Fehsenfeld, F. C., Holloway, J. S., Hubler, G., Nicks, D. K., Nowak, J. B., Parrish, D. D., Ryerson, T. B., Atlas, E. L., Donnelly, S. G., Schauffler, S. M., Stroud, V., Johnson, K., Carmichael, G. R., and Streets, D. G.: Chemical composition of air masses transported from Asia to the U.S. West Coast during ITCT 2K2: Fossil fuel combustion versus biomass-burning signatures, J. Geophys. Res., 109, D18308, doi:10.1029/2003JD004202, 2004.

de Gouw, J. A., Middlebrook, A. M., Warneke, C., Goldan, P. D., Kuster, W. C., Roberts, J. M., Fehsenfeld, F. C., Worsnop, D. R., Canagaratna, M. R., Pszenny, A. A. P., Keene, W. C., Marchewka, M., Bertman, S. B., and Bates, T. S.: Budget of organic carbon in a polluted atmosphere: Results from the New England Air Quality Study in 2002, J. Geophys. Res.-Atmos., 110, D16, doi:10.1029/2004JD005623, 2005.

Finlayson-Pitts, B. J. and Pitts Jr., J. N.: Atmospheric Chemistry: Fundamentals and Experimental Techniques, John Wiley \& Sons, New York, 1986.

Fried, A., Lee, Y. N., Frost, G., Wert, B., Henry, B., Drummond, J. R., Hubler, G., and Jobson, T.: Airborne $\mathrm{CH}_{2} \mathrm{O}$ measurements over the North Atlantic during the 1997 NARE campaign: Instrument comparisons and distributions, J. Geophys. Res.-Atmos., 107, 4039, doi:10.1029/2000jd000260, 2002.

Fried, A., Wang, Y. H., Cantrell, C., Wert, B., Walega, J., Ridley, B., Atlas, E., Shetter, R., Lefer, B., Coffey, M. T., Hannigan, J., Blake, D., Blake, N., Meinardi, S., Talbot, B., Dibb, J., Scheuer, E., Wingenter, O., Snow, J., Heikes, B., and Ehhalt, D.: Tunable diode laser measurements of formaldehyde during the TOPSE 2000 study: Distributions, trends, and model comparisons, J. Geophys. Res.-Atmos., 108, 8365, doi:10.1029/2002jd002208, 2003.

Fried, A., Walega, J. G., Olson, J. R., Crawford, J. H., Chen, G., Weibring, P., Richter, D., Roller, C., Tittel, F. K., Heikes, B. G., Snow, J. A., Shen, H. W., O'Sullivan, D. W., Porter, M., Fuelberg, H., Halland, J., and Millet, D. B.: Formaldehyde over North America and the North Atlantic during the summer 2004 INTEX campaign: Methods, observed distributions, and measurementmodel comparisons, J. Geophys. Res.-Atmos., 113, D10302, doi:10.1029/2007jd009185, 2008.
Garcia, A. R., Volkamer, R., Molina, L. T., Molina, M. J., Samuelson, J., Mellqvist, J., Galle, B., Herndon, S. C., and Kolb, C. E.: Separation of emitted and photochemical formaldehyde in Mexico City using a statistical analysis and a new pair of gas-phase tracers, Atmos. Chem. Phys., 6, 4545-4557, doi:10.5194/acp-64545-2006, 2006.

Gilman, J. B., Kuster, W. C., Goldan, P. D., Herndon, S. C., Zahniser, M. S., Tucker, S. C., Brewer, W. A., Lerner, B. M., Williams, E. J., Harley, R. A., Fehsenfeld, F. C., Warneke, C., and de Gouw, J. A.: Measurements of volatile organic compounds during the 2006 TexAQS/GoMACCS campaign: Industrial influences, regional characteristics, and diurnal dependencies of the $\mathrm{OH}$ reactivity, J. Geophys. Res.-Atmos., 114, D00f06, doi:10.1029/2008jd011525, 2009.

Gilman, J. B., Burkhart, J. F., Lerner, B. M., Williams, E. J., Kuster, W. C., Goldan, P. D., Murphy, P. C., Warneke, C., Fowler, C., Montzka, S. A., Miller, B. R., Miller, L., Oltmans, S. J., Ryerson, T. B., Cooper, O. R., Stohl, A., and de Gouw, J. A.: Ozone variability and halogen oxidation within the Arctic and sub-Arctic springtime boundary layer, Atmos. Chem. Phys., 10, 10223-10236, doi:10.5194/acp-10-10223-2010, 2010.

Gilpin, T., Apel, E. C., Fried, A., Sewell, S., Wert, B., Calvert, J. G., Genfa, Z., Dasgupta, P., Harder, J., Heikes, B., Hopkins, B., Westberg, H., Kleindienst, T., Lee, Y.-N., Zhou, X., and Lonneman, W.: Intercomparison of six ambient $\left[\mathrm{CH}_{2} \mathrm{O}\right]$ techniques, J. Geophys. Res., 102, 21161-121188, 1997.

Grosjean, D. and Fung, K.: Collection efficiencies of cartridges and micro-impingers for sampling of aldehydes in air as 2,4dinitrophenylhydrazones, Anal. Chem., 54, 1221-1224, 1982.

Guenther, A. B., Geron, C., Pierce, T., Lamb, B., Harley, R. A., and Fall, R.: Natural emissions of non-methane volatile organic compounds; carbon monoxide, and oxides of nitrogen from North America, Atmos. Environ., 34, 2205-2230, 2000.

Hak, C., Pundt, I., Trick, S., Kern, C., Platt, U., Dommen, J., Ordóñez, C., Prévôt, A. S. H., Junkermann, W., Astorga-Lloréns, C., Larsen, B. R., Mellqvist, J., Strandberg, A., Yu, Y., Galle, B., Kleffmann, J., Lörzer, J. C., Braathen, G. O., and Volkamer, R.: Intercomparison of four different in-situ techniques for ambient formaldehyde measurements in urban air, Atmos. Chem. Phys., 5, 2881-2900, doi:10.5194/acp-5-2881-2005, 2005.

Hansel, A., Singer, W., Wisthaler, A., Schwarzmann, M., and Lindinger, W.: Energy dependencies of the proton transfer reactions $\mathrm{H}_{3} \mathrm{O}(+)+\mathrm{CH}_{2} \mathrm{O}$ double left right arrow $\mathrm{CH}_{2} \mathrm{OH}++\mathrm{H}_{2} \mathrm{O}$, Int. J. Mass Spectrom., 167, 697-703, 1997.

Heckel, A., Richter, A., Tarsu, T., Wittrock, F., Hak, C., Pundt, I., Junkermann, W., and Burrows, J. P.: MAX-DOAS measurements of formaldehyde in the Po-Valley, Atmos. Chem. Phys., 5, 909918, doi:10.5194/acp-5-909-2005, 2005.

Herndon, S. C., Zahniser, M. S., Nelson, D. D., Shorter, J., McManus, J. B., Jimenez, R., Warneke, C., and de Gouw, J. A.: Airborne measurements of $\mathrm{HCHO}$ and $\mathrm{HCOOH}$ during the New England Air Quality Study 2004 using a pulsed quantum cascade laser spectrometer, J. Geophys. Res.-Atmos., 112, D10s03, doi:10.1029/2006jd007600, 2007.

Holloway, J. S., Jakoubek, R. O., Parrish, D. D., Gerbig, C., VolzThomas, A., Schmitgen, S., Fried, A., Wert, B., Henry, B., and Drummond, J. R.: Airborne intercomparison of vacuum ultraviolet fluorescence and tunable diode laser absorption measurements of tropospheric carbon monoxide, J. Geophys. Res., 105, 
24251-224261, doi:2000JD900237, 2000.

Holzinger, R., Warneke, C., Hansel, A., Jordan, A., Lindinger, W., Scharffe, D. H., Schade, G., and Crutzen, P. J.: Biomass burning as a source of formaldehyde, acetaldehyde, methanol, acetone, acetonitrile, and hydrogen cyanide, Geophys. Res. Lett., 26, 1161-1164, 1999.

Hottle, J. R., Huisman, A. J., Digangi, J. P., Kammrath, A., Galloway, M. M., Coens, K. L., and Keutsch, F. N.: A Laser Induced Fluorescence-Based Instrument for In-Situ Measurements of Atmospheric Formaldehyde, Environ. Sci. Technol., 43, 790-795, doi:10.1021/es801621f, 2009.

Inomata, S., Tanimoto, H., Kameyama, S., Tsunogai, U., Irie, H., Kanaya, Y., and Wang, Z.: Technical Note: Determination of formaldehyde mixing ratios in air with PTR-MS: laboratory experiments and field measurements, Atmos. Chem. Phys., 8, 273284, doi:10.5194/acp-8-273-2008, 2008.

Jobson, B. T. and McCoskey, J. K.: Sample drying to improve $\mathrm{HCHO}$ measurements by PTR-MS instruments: laboratory and field measurements, Atmos. Chem. Phys., 10, 1821-1835, doi:10.5194/acp-10-1821-2010, 2010.

Jordan, A., Haidacher, S., Hanel, G., Hartungen, E., Herbig, J., Mark, L., Schottkowsky, R., Seehauser, H., Sulzer, P., and Mark, T. D.: An online ultra-high sensitivity Proton-transfer-reaction mass-spectrometer combined with switchable reagent ion capability (PTR+SRI-MS), Int. J. Mass Spectrom., 286, 32-38, doi:10.1016/j.ijms.2009.06.006, 2009.

Junkermann, W. and Burger, J. M.: A new portable instrument for continuous measurement of formaldehyde in ambient air, J. Atmos. Ocean. Tech., 23, 38-45, 2006.

Karl, T., Jobson, B. T., Kuster, W. C., Williams, E. J., Stutz, J., Shetter, R., Hall, S. R., Goldan, P. D., Fehsenfeld, F. C., and Lindinger, W.: Use of proton-transfer-reaction mass spectrometry to characterize volatile organic compound sources at the La Porte super site during the Texas Air Quality Study 2000, J. Geophys. Res., 108, 4508, doi:10.1029/2002JD003333, 2003.

Kelly, T. J. and Fortune, C. R.: Continuous monitoring of gaseous formaldehyde using an improved fluorescence approach, Int. J. Environ. Anal. Chem., 54, 249-263, 1994.

Kormann, R., Fischer, H., de Reus, M., Lawrence, M., Brühl, Ch., von Kuhlmann, R., Holzinger, R., Williams, J., Lelieveld, J., Warneke, C., de Gouw, J., Heland, J., Ziereis, H., and Schlager, H.: Formaldehyde over the eastern Mediterranean during MINOS: Comparison of airborne in-situ measurements with 3D-model results, Atmos. Chem. Phys., 3, 851-861, doi:10.5194/acp-3-851-2003, 2003.

Lawson, D. R., Biermann, H. W., Tuazon, E. C., Winer, A. M., Mackay, G. I., Schiff, H. I., Kok, G. L., Dasgupta, P. K., and Fung, K.: Formaldehyde measurement methods evaluation and ambient concentrations during the carbonaeous species methods comparison study, Aerosol Sci. Tech., 12, 64-76, 1990.

Lee, Y. N., Zhou, X., Kleinman, L. I., Nunnermacker, L. J., Springston, S. R., Daum, P. H., Newman, L., Keigley, W. G., Holdren, M. W., Spicer, C. W., Young, V., Fu, B., Parrish, D. D., Holloway, J., Williams, J., Roberts, J. M., Ryerson, T. B., and Fehsenfeld, F. C.: Atmospheric chemistry and distribution of formaldehyde and several multioxygenated carbonyl compounds during the 1995 Nashville Middle Tennessee Ozone Study, J. Geophys. Res.-Atmos., 103, 22449-22462, 1998.
Li, S. M., Anlauf, K. G., Wiebe, H. A., and Bottenheim, J. W.: Estimating primary and secondary production of hcho in eastern north-america based on gas-phase measurements and principal component analysis, Geophys. Res. Lett., 21, 669-672, 1994.

Lowe, D. C. and Schmidt, U.: Formaldehyde (HCHO) measurements in the nonurban atmosphere, J. Geophys. Res.-Oceans, 88 , 844-858, doi:10.1029/JC088iC15p10844, 1983.

Meller, R. and Moortgat, G. K.: Temperature dependence of the absorption cross sections of formaldehyde between 223 and $323 \mathrm{~K}$ in the wavelength range $225-375 \mathrm{~nm}$, J. Geophys. Res.-Atmos., 105, 7089-7101, 2000.

Millet, D. B., Jacob, D. J., Boersma, K. F., Fu, T. M., Kurosu, T. P., Chance, K., Heald, C. L., and Guenther, A.: Spatial distribution of isoprene emissions from North America derived from formaldehyde column measurements by the OMI satellite sensor, J. Geophys. Res.-Atmos., 113, D02307, doi:10.1029/2007jd008950, 2008.

Neuman, J. A., Ryerson, T. B., Huey, L. G., Jakoubek, R., Nowak, J. B., Simons, C., and Fehsenfeld, F. C.: Calibration and evaluation of nitric acid and ammonia permeation tubes by UV optical absorption, Environ. Sci. Technol., 37, 2975-2981, doi:10.1021/es0264221, 2003.

Palmer, P. I., Abbot, D. S., Fu, T. M., Jacob, D. J., Chance, K., Kurosu, T. P., Guenther, A., Wiedinmyer, C., Stanton, J. C., Pilling, M. J., Pressley, S. N., Lamb, B., and Sumner, A. L.: Quantifying the seasonal and interannual variability of North American isoprene emissions using satellite observations of the formaldehyde column, J. Geophys. Res.-Atmos., 111, D12, doi:10.1029/2005JD006689, 2006.

Platt, U. and Stutz, J.: Differential Optical Absorption Spectroscopy: Principles and Applications, ISBN 978-3540211938, Springer, Heidelberg, New York, 2008.

Rappenglück, B., Dasgupta, P. K., Leuchner, M., Li, Q., and Luke, W.: Formaldehyde and its relation to $\mathrm{CO}, \mathrm{PAN}$, and $\mathrm{SO}_{2}$ in the Houston-Galveston airshed, Atmos. Chem. Phys., 10, 24132424, doi:10.5194/acp-10-2413-2010, 2010.

Steinbacher, M., Dommen, J., Ammann, C., Spirig, C., Neftel, A., and Prevot, A. S. H.: Performance characteristics of a protontransfer-reaction mass spectrometer (PTR-MS) derived from laboratory and field measurements, Int. J. Mass Spectrom., 239, 117-128, 2004.

Stutz, J. and Platt, U.: Numerical analysis and estimation of the statistical error of differential optical absorption spectroscopy measurements with least-squares methods, Appl. Optics, 35, 60416053, 1996.

Stutz, J. and Platt, U.: Improving long-path differential optical absorption spectroscopy with a quartz-fiber mode mixer, Appl. Optics, 36, 1105-1115, 1997.

Sumner, A. L., Shepson, P. B., Grannas, A. M., Bottenheim, J. W., Anlauf, K. G., Worthy, D., Schroeder, W. H., Steffen, A., Domine, F., Perrier, S., and Houdier, S.: Atmospheric chemistry of formaldehyde in the Arctic troposphere at Polar Sunrise, and the influence of the snowpack, Atmos. Environ., 36, 2553-2562, 2002.

Veres, P., Gilman, J. B., Roberts, J. M., Kuster, W. C., Warneke, C., Burling, I. R., and de Gouw, J.: Development and validation of a portable gas phase standard generation and calibration system for volatile organic compounds, Atmos. Meas. Tech., 3, 683691, doi:10.5194/amt-3-683-2010, 2010. 
Vlasenko, A., Macdonald, A .M., Sjostedt, S. J., and Abbatt, J. P. D.: Formaldehyde measurements by Proton transfer reaction Mass Spectrometry (PTR-MS): correction for humidity effects, Atmos. Meas. Tech., 3, 1055-1062, doi:10.5194/amt-3-10552010, 2010.

Volkamer, R., Sheehy, P., Molina, L. T., and Molina, M. J.: Oxidative capacity of the Mexico City atmosphere - Part 1: A radical source perspective, Atmos. Chem. Phys., 10, 6969-6991, doi:10.5194/acp-10-6969-2010, 2010.

Warneke, C., van der Veen, C., Luxembourg, S., de Gouw, J. A., and Kok, A.: Measurements of benzene and toluene in ambient air using proton-transfer-reaction mass spectrometry: calibration, humidity dependence, and field intercomparison, Int. J. Mass Spectrom., 207, 167-182, 2001.

Warneke, C., De Gouw, J. A., Kuster, W. C., Goldan, P. D., and Fall, R.: Validation of atmospheric VOC measurements by proton-transfer-reaction mass spectrometry using a gaschromatographic preseparation method, Environ. Sci. Technol., 37, 2494-2501, doi:10.1021/es026266i, 2003.

Warneke, C., de Gouw, J. A., Goldan, P. D., Kuster, W. C., Williams, E. J., Lerner, B. M., Jakoubek, R., Brown, S. S., Stark, H., Aldener, M., Ravishankara, A. R., Roberts, J. M., Marchewka, M., Bertman, S., Sueper, D. T., McKeen, S. A., Meagher, J. F., and Fehsenfeld, F. C.: Comparison of daytime and nighttime oxidation of biogenic and anthropogenic VOCs along the New England coast in summer during New England Air Quality Study 2002, J. Geophys. Res.-Atmos., 109, D10, doi:10.1029/2003JD004424, 2004.

Warneke, C., de Gouw, J. A., Lovejoy, E. R., Murphy, P. C., Kuster, W. C., and Fall, R.: Development of proton-transfer ion trap-mass spectrometry: On-line detection and identification of volatile organic compounds in air, J. Am. Soc. Mass Spectrom., 16, 1316-1324, 2005.

Warneke, C., McKeen, S. A., de Gouw, J. A., Goldan, P. D., Kuster, W. C., Holloway, J. S., Williams, E. J., Lerner, B. M., Parrish, D. D., Trainer, M., Fehsenfeld, F. C., Kato, S., Atlas, E. L., Baker, A., and Blake, D. R.: Determination of urban volatile organic compound emission ratios and comparison with an emissions database, J. Geophys. Res.-Atmos., 112, D10S47, doi:10.1029/2006JD007930, 2007.

Warneke, C., de Gouw, J. A., Del Negro, L., Brioude, J., McKeen, S., Stark, H., Kuster, W. C., Goldan, P. D., Trainer, M., Fehsenfeld, F. C., Wiedinmyer, C., Guenther, A. B., Hansel, A., Wisthaler, A., Atlas, E., Holloway, J. S., Ryerson, T. B., Peischl, J., Huey, L. G., and Hanks, A. T. C.: Biogenic emission measurement and inventories determination of biogenic emissions in the eastern United States and Texas and comparison with biogenic emission inventories, J. Geophys. Res.-Atmos., 115, D00f18, doi:10.1029/2009jd012445, 2010a.
Warneke, C., Froyd, K. D., Brioude, J., Bahreini, R., Brock, C. A., Cozic, J., de Gouw, J. A., Fahey, D. W., Ferrare, R., Holloway, J. S., Middlebrook, A. M., Miller, L., Montzka, S., Schwarz, J. P., Sodemann, H., Spackman, J. R., and Stohl, A.: An important contribution to springtime Arctic aerosol from biomass burning in Russia, Geophys. Res. Lett., 37, L01801, doi:10.1029/2009gl041816, 2010b.

Washenfelder, R. A., Trainer, M., Frost, G. J., Ryerson, T. B., Atlas, E. L., de Gouw, J. A., Flocke, F. M., Fried, A., Holloway, J. S., Parrish, D. D., Peischl, J., Richter, D., Schauffler, S. M., Walega, J. G., Warneke, C., Weibring, P., and Zheng, W.: Characterization of $\mathrm{NO}_{\mathrm{x}}, \mathrm{SO}_{2}$, ethene, and propene from industrial emission sources in Houston, Texas, J. Geophys. Res.-Atmos., 115, D16311, doi:10.1029/2009jd013645, 2010.

Weibring, P., Richter, D., Walega, J. G., and Fried, A.: First demonstration of a high performance difference frequency spectrometer on airborne platforms, Opt. Express, 15, 13476-13495, 2007.

Wert, B. P., Fried, A., Henry, B., and Cartier, S.: Evaluation of inlets used for the airborne measurement of formaldehyde, J. Geophys. Res.-Atmos., 107, 4163, doi:10.1029/2001jd001072, 2002.

Wert, B. P., Fried, A., Rauenbuehler, S., Walega, J., and Henry, B.: Design and performance of a tunable diode laser absorption spectrometer for airborne formaldehyde measurements, J. Geophys. Res.-Atmos., 108, 4350, doi:10.1029/2002jd002872, 2003.

Wisthaler, A., Apel, E. C., Bossmeyer, J., Hansel, A., Junkermann, W., Koppmann, R., Meier, R., Müller, K., Solomon, S. J., Steinbrecher, R., Tillmann, R., and Brauers, T.: Technical Note: Intercomparison of formaldehyde measurements at the atmosphere simulation chamber SAPHIR, Atmos. Chem. Phys., 8, 21892200, doi:10.5194/acp-8-2189-2008, 2008.

Yokelson, R. J., Griffith, D. W. T., and Ward, D. E.: Openpath Fourier transform infrared studies of large-scale laboratory biomass fires, J. Geophys. Res.-Atmos., 101, 21067-21080, 1996.

Zavala, M., Herndon, S. C., Wood, E. C., Onasch, T. B., Knighton, W. B., Marr, L. C., Kolb, C. E., and Molina, L. T.: Evaluation of mobile emissions contributions to Mexico City's emissions inventory using on-road and cross-road emission measurements and ambient data, Atmos. Chem. Phys., 9, 6305-6317, doi:10.5194/acp-9-6305-2009, 2009. 